\title{
ЕКОЛОГО-ЕКОНОМІЧНІ ОСНОВИ ФОРМУВАННЯ ЗЕМЛЕКОРИСТУВАННЯ ТЕРИТОРІЙ ПРИРОДНО- ЗАПОВІДНОГО ФОНДУ У СКЛАДІ ЕКОЛОГІЧНОЇ МЕРЕЖІ УКРАЇНИ
}

\author{
Гетманьчик Іванна Петрівна, \\ кандидат економічних наук, заступник директора з виховної роботи, \\ ВСП «Боярський фаховий коледж Національного університету біоресурсів $i$ \\ природокористування України», Украӥна \\ Рубан Ольга Олександрівна, \\ кандидат економічних наук, асистент кафедри економіки прачі та соиіального розвитку, \\ Національного університету біоресурсів і природокористування України, Україна \\ Грицишин Наталія Михайлівна, \\ завідувачка технічного відділення, ВСП «Боярський фаховий коледж Начіонального \\ університету біоресурсів і природокористування України», Украӥна \\ DOI: https://doi.org/10.31435/rsglobal_conf/25112020/7242
}

\begin{abstract}
Economic and environmental measures related to the formation of nature reserves as key elements of the ecological network of Ukraine are considered. It is shown that in conditions of prevailing private ownership of land, a significant role is played by the forced alienation of land plots promising for conservation, as well as the establishment of environmental restrictions in land use. At the same time, the needs of the economy in land resources should be balanced with the requirements of environmental protection and biodiversity conservation. The additional benefits of creating conservation areas for the local population, which are associated with the creation of healthier living conditions and improving the quality of life, preventing the degradation of natural resources and reducing their pollution, are emphasized. The essence of spatial organization of the conditions of conservation of biological diversity in Ukraine through the formation of land-use areas of nature reserve fund is determined. An approach to improving the ecological and economic bases of the formation of land use areas of nature reserve fund, in particular, in the ecological network in Ukraine is given.
\end{abstract}

Keywords: protected areas, ecological network, environmental restrictions, land use.

Вступ. На даному етапі розвитку нових земельних відносин використання земельних ресурсів не повною мірою відповідає вимогам раціонального природокористування. Земельні ресурси України $(60354,8$ тис. га) характеризуються надзвичайно високим рівнем освоєння. Крім того, має місце недостатнє економічне та екологічне обгрунтування розподілу земель за цільовим призначенням.

Аналізуючи економічну сутність земельних ресурсів, як складової частини природних ресурсів зазначимо, що характерною особливістю сучасного розвитку економіки є її екологічна розбалансованість, яка зумовлює негативні зміни в природному довкіллі та генерує інфляційні процеси. Нарощування виробництва товарів і послуг без урахування екологічних детермінант збереження природного капіталу призводить до дедалі більшого його виснаження.

Зазначена проблема є досить важливою для України, яка має екологічно розбалансовану економіку, не ефективно використовувані природні ресурси, забруднене довкілля. Тому для збереження й відтворення природної частини земельних ресурсів потрібно визначити напрями та передумови їх збереження й ефективного використання у вітчизняній економіці, які б узгоджувалися із соціальними, економічними та екологічними параметрами розвитку.

Велике соціальне та екологічне значення мають землі природно-заповідного призначення. За останні десятиріччя площа територій та об'єктів природно-заповідного фонду зросла більш як удвічі. Однак цього недостатньо, оскільки за стандартами країн Європейського Союзу екомережа має становити понад 10 \% території країни [6].

Тому наприкінці XX - на початку XXI ст. конче зрозумілою стала потреба в створенні неперервної мережі природоохоронних об'єктів.

За таких умов, проблеми формування екологічної мережі України набувають значної актуальності. 
Результати дослідження. Головною метою при сталому землекористуванні є не лише досягнення стану рівноваги між екологічними та економічними інтересами, а й обмеження кількісного зростання параметрів чисельності населення, техногенного навантаження тощо в екосистемі з подальшим його утриманням (коливанням) у діапазоні сталості.

Екологобезпечне використання земель змушує сприйняти екологічну парадигму розвитку, в основі якої лежить необхідність забезпечення умов виживання людства в середовищі, зміненому його ж діяльністю, та передбачає використання землі за таких умов, які гарантують недопущення незворотних екологічних наслідків та не знижують здатність ефективного функціонування екосистем. Зважаючи на вищезазначене, пропонуємо трактувати поняття «екологобезпечне використання земель» як територіально-просторове використання землі в балансокруговому процесі взаємовідносин земля - користувач у межах ємності екосистем за умов, які гарантують певний стан захищеності, недопущення незворотних екологічних процесів на землі та забезпеченості умов виживання людства [3].

Формування екологічних видів землекористування дозволить розв'язати одразу три економічно, екологічно й соціально значимі проблеми:

1) зменшити затрати на ліквідацію наслідків забруднень земельних угідь синтезованими хімічними речовинами, які застосовуються в сільськогосподарській діяльності людини;

2) сприяти попередженню деградаційних процесів у грунтах, які виникають за інтенсивного ведення сільського господарства;

3) покращити стан здоров’я населення внаслідок уживання екологічно чистої продукції.

Відповідно до Закону України «Про екологічну мережу України» [1] проектування екомережі здійснюється шляхом розроблення регіональних схем формування екомережі Автономної Республіки Крим та областей, а також місцевих схем формування екомережі районів, населених пунктів та інших територій України. Для надання завершеності процесу формування екологічної мережі на місцевому рівні нами пропонується здійснювати розробку проектів землеустрою щодо формування землекористування екомережі територій сільських, селищних і міських рад. Першим етапом формування землекористування екомережі $\epsilon$ аналіз та оцінка специфіки землекористування складових екомережі в межах адміністративних утворень за рядом позицій. Практично кожне адміністративне утворення 3 точки зору природної структури як одиниця, тою чи іншою мірою, штучна. Адміністративні утворення, як правило, не збігаються 3 природними межами, тому ні флористичні, ні синдинамічні критерії, незважаючи на їх природність та безумовну необхідність не $\epsilon$ достатніми. Формування землекористування, особливо сільськогосподарського i природоохоронного, необхідно здійснювати з урахуванням ландшафтних критеріїв.

Ландшафтні критерії тісно корелюють 3 біологічними, які є основними для вибору земельних угідь, що включаються в екомережу. Особливо важливим є тісний зв'язок між показниками біорізноманіття та характеристиками просторової структури ландшафту, під яким розуміється кількісне співвідношення та просторове розподілення різних елементів ландшафту. Аналіз землекористування в межах адміністративно-територіальних утворень бажано проводити з використанням картографічних та інших матеріалів із землеустрою. Це дозволяє виділити ландшафтні елементи різних груп за ступенем змін ландшафту. Таку мережу ландшафтних утворень необхідно розглядати, як територію структурного елементу екомережі локального масштабу. Структурні елементи формування землекористування екомережі, в тому числі природно-заповідного фонду визначаються за об'єктивно обумовленими природними чинниками, просторовими параметрами екосистем та інших типів територіальних утворень.

Таким чином, структурні елементи формування землекористування територій природно-заповідного фонду, як складової частини екомережі включають: землекористування основних територій та об'єктів природно-заповідного фонду, землекористування буферної території, землекористування відновлювальної території. Вони у своій неперервній єдності утворюють землекористування екомережі, яке функціонально об'єднує осередки біорізноманіття в єдину регіональну та національну систему.

Під час вибору землекористування основних територій та об'єктів природно-заповідного фонду враховується загальний стан природного рослинного покриву та тваринного світу регіону. Вибір землекористування основних територій та об’єктів природно-заповідного фонду доцільно здійснювати 3 урахуванням не лише сучасного стану біоти, а й можливостей іiі відновлення у майбутньому. У першу чергу, включаються території та об'єкти природно-заповідного фонду 
(природні та біосферні заповідники, національні природні парки, а також значні за площею заказники та заповідні урочища, регіональні ландшафтні парки тощо); земельні ділянки, на яких зростають рослинні угруповання, занесені до Зеленої книги України; території, які $є$ місцями перебування чи зростання видів тваринного та рослинного світу, занесених до Червоної книги України. А також землі водного фонду, водно-болотні угіддя, водоохоронні зони; землі лісового фонду; частково землі оздоровчого призначення 3 їх природними ресурсами; інші природні території та об'єкти (ділянки степової рослинності, пасовища, сіножаті, кам'яні відслонення, піски, солончаки, земельні ділянки, в межах яких є природні об'єкти, що мають особливу природну цінність); частково землі сільськогосподарського призначення екстенсивного використання - пасовища, луки, сіножаті тощо. В особливих випадках до землекористування основних територій природно-заповідного фонду включаються радіоактивно забруднені землі, що не використовуються та підлягають особливій охороні як природні регіони з окремим статусом.

Критерії вибору землекористування буферної території є перехідними смугами між природними територіями та територіями господарського використання. Основною функцією землекористування буферної території є забезпечення захисту територіальних елементів екомережі від негативного антропогенного впливу. Вони повинні мати площу, достатню для захисту землекористування основних територій та об'єктів природно-заповідного фонду від дії зовнішніх негативних факторів і оптимізації певних форм господарювання з метою збереження існуючих і відновлення втрачених природних цінностей. До складових землекористування буферної території можуть включатися буферні зони природних і біосферних заповідників і національних природних парків; частково землі водного фонду та водоохоронні зони; частково землі лісового фонду; інші заліснені території, у тому числі лісові смуги та інші захисні насадження, які не належать до земель лісового фонду; землі рекреаційного призначення, які використовуються для організації масового відпочинку населення, туризму та проведення спортивних заходів; частково землі сільськогосподарського призначення екстенсивного використання - пасовища, луки, сіножаті тощо.

Критерії вибору землекористування відновлювальної території створюються зі складових елементів екомережі з метою подальшого розвитку та удосконалення функціонування природнозаповідного фонду. Це території, на яких необхідно й можливо відновити природний рослинний покрив, здійснити репатріацію видів рослин і тварин. Основними критеріями вибору землекористування відновлювальної території $є$ збереження на них середовищ існування, навіть якщо природне біорізноманіття повністю знищено (осушені торфовища, деградовані лучні та степові природні пасовища, зріджені ліси, агроценози інтенсивного використання), реальна можливість проведення ренатуралізаційних заходів. Відновлення екологічних зв'язків між природними територіями може здійснюватися як природними, так і штучними шляхами посадкою лісу, залуженням прибережних смуг вздовж річок тощо.

До складових землекористування відновлювальної території належать земельні угіддя, які повинні відігравати функцію взаємозв'язків біоти з основними територіями: здавна орані, низькопродуктивні; вдруге засолені, внаслідок надмірного зрошення; пасовищні збої, ділянки прогону худоби та місця його постійної концентрації; забур'янені карантинними видами бур'янів, у т.ч. шкідливими для здоров'я людей; кар'єри, відвали породи тощо; орні землі на схилах, які відводяться під грунтозахисні смуги, або постійні ділянки, призначені для розведення диких комах-запилювачів; схили насипів і смуги відчуження вздовж автомобільних доріг, залізниць, нафто - і газопроводів, ЛЕП та інших комунікацій; ділянки відкритих грунтів, на яких відбуваються, або можуть розвинутися яружні та зсувні процеси; місця постійного відпочинку та інші рекреаційні території; ділянки, які підлягають довгостроковій консервації внаслідок радіаційного, хімічного або іншого забруднення, яке становить загрозу здоров’ю людей і тварин; селітебні території, які підлягають рекультивації - садиби, занедбані ферми тощо.

Основна мета формування національної екологічної мережі полягає у збільшенні площі природних територій до рівня, з одного боку, достатнього для забезпечення збалансованого використання і відтворення біотичних ресурсів, а 3 другого - адекватного екологічнобезпечному господарському використанню земель [2].

В умовах надмірної освоєності земель, формування національної екомережі України, як єдиної територіальної системи, має на меті доведення складових земельного фонду країни, на яких наявні умови для збереження та відтворення природного різноманіття ландшафтів, місць існування рослин і тварин до рівня, достатнього для забезпечення просторової єдності окремих ділянок природних територій. 
Для виконання ролі окремої функціональної складової території країни екомережа потребує такої частки земель країни та в такій територіальній структурі, що є достатні для виконання нею ії призначення.

При цьому необхідно забезпечити:

• відповідність просторової форми екомережі вимогам функціонування природних геосистем;

- представленість у складі екомережі існуючих видів природних геосистем країни; режимі;

- обгрунтування заходів щодо функціонування природних комплексів у природному

- першочергове залучення до національної екологічної мережі сільськогосподарських земель, сучасне використання яких $є$ недоцільним з екологічної та економічної точок зору [4].

\section{Проблемні питання щодо створення екомережі в Україні.}

У законодавстві не визначено зв'язок об'єктів природно-заповідного фонду 3 структурними елементами екомережі (ключових, буферних, відновлювальних та сполучних територій - екокоридорів), не встановлено режими господарювання на цих територіях, не визначено, до якої категорії земель відносяться структурні елементи екомережі.

Правовий статус структурних елементів екологічної мережі потребує уточнення та доопрацювання, адже ці елементи не мають встановлених законодавством режимів землекористування та природокористування. Згідно 3 чинним законодавством, як режим землекористування, так і ступінь його обмеження майже цілком залежать від доброї волі землевласників і землекористувачів (ім заборонено тільки змінювати цільове призначення земель). Домогтися підтримки добровільного введення обмежень землекористування землевласниками і землекористувачами важко, оскільки ні Український уряд, ні Мінприроди не компенсують їм сільськогосподарські та інші збитки, викликані такими обмеженнями [6].

До інших чинників, що гальмують формування екомережі, належать відсутність методичної допомоги регіональним органам виконавчої влади та органам місцевого самоврядування; часті зміни норм у Земельному, Водному, Лісовому кодексах, інших законодавчих i нормативних актах без належного врахування потреб розвитку екомережі. Зокрема, не визначені такі практичні аспекти формування та державної реєстрації територіальних природоохоронних обмежень (обтяжень) екокоридорів і можливі наслідки встановлення екокоридорів для землевласників і землекористувачів. Така сама невизначеність існує й по відношенню до буферних і відновлювальних територій.

Існуючі природоохоронні обмеження в екомережі України.

Збереження природно цінного статусу територій в умовах впливу діяльності людини передбачає введення і використання певних правил, норм, режимів природокористування. Ці правила можуть мати рекомендаційний характер заходів, які сприяють збереженню чи підвищенню природної значимості території, але можуть мати характер обмежень щодо природокористування. Існуюча система функціонування територій і об'єктів природно-заповідного фонду в Україні базується на забороні певних видів діяльності або введенні певних обмежень, які сформульовані в законах i нормативних документах. Очевидно, що землекористування екомережі, яке має природоохоронний характер, також повинно відповідати нормам обмежувальної діяльності людини. Єдине обмеження сформульовано в пункті 3 Статті 6 Закону України «Про екологічну мережу України»: власники і користувачі територій та об'єктів, включених до переліків територій та об'єктів екомережі, зобов'язані забезпечувати їх використання за цільовим призначенням. Територіями та об’єктами екомережі є структурні елементи екомережі, до яких відносяться ключові, сполучні, буферні та відновлювані території. Отже, закон ввів не заборону на зміну функціонального та дозволеного використання земель і інших природних ресурсів, а вказує на обов'язок забезпечувати використання земель за цільовим призначенням [1].

Таким чином, згідно з чинним законодавством правовий статус земель не змінюється після створення на них структурних елементів екомережі і згідно з законодавством ніяких додаткових обмежень на користування природними ресурсам земельної ділянки власника земельної ділянки чи землекористувача не вводиться.

Надання особливого правового статусу структурним елементам екомережі.

Правовий статус (режим) земель структурних елементів екомережі визначено в Законі України «Про екологічну мережу України» [1]. Проте дана законодавча база ефективно не регулює правовідносини із визначення і забезпечення належного режиму діяльності людини на 
землях елементів екомережі, як на територіях з особливим природоохоронним статусом. Зокрема, не визначено систему і порядок впровадження природоохоронних заходів та обмежень для різних категорій земель елементів екомережі, не достатньо повно врегульовано порядок державного управління у цій сфері, не визначена відповідальність за правопорушення встановленого режиму земель елементів екомережі (даний об’єкт може виступати лише як додатковий у ряді визначених законодавством правопорушень). Таким чином, без зміни окреслених норм оперативне формування ефективної екомережі $\epsilon$, принаймні, значно ускладненим.

Існує два шляхи введення обмеження користування земельною ділянкою - законом, або договором. Проте особливий правовий статус земельної ділянки не встановлюється Договором. Але в певних випадках введення для структурних елементів екомережі обмежень договором $\epsilon$ можливим і корисним.

Чинне законодавство щодо екомережі має тільки одне згадане обмеження - щодо забезпечення використання цільового призначення, але воно не ефективне. У зв'язку з цим, особливий правовий статус (режим) земель структурних елементів екомережі, необхідний для виконання ними своїх функцій у формуванні просторово цілісної екомережі доцільно ввести шляхом внесення змін до законів.

Основним економічним критерієм прийняття управлінських рішень про розвиток системи екологобезпечного землекористування $\epsilon$ економічна оцінка, щодо наслідків впливу на земельні ресурси та навколишнє середовище, зміни цільового використання земель та оцінка еколого-економічної ефективності проектів землеустрою щодо впорядкування землеволодінь і землекористувань, співвіднесених з одержуваними вигодами. Вперше такий підхід був запропонований американським ученим Джоном Діксоном й одержав підтримку Всесвітнього Банку.

Підхід полягає у включенні в традиційний управлінський i проектний аналіз екологічних і соціальних втрат, які можуть виникати в результаті прийняття управлінських рішень або реалізації проектів землеустрою. Оцінка ефективності управлінських рішень або проектів землеустрою визначається, виходячи із співвідношення можливих доходів не тільки інвесторів і власників землі, але й з урахуванням втрат і витрат територіальних громад в результаті втрати позитивних ефектів від недооцінюваних екологічних благ. До втрат відносять збиток, викликаний втратою природних благ і природних об'єктів, включаючи й соціальні аспекти (зниження вартості природних ресурсів, збільшення витрат на лікування населення). Якщо дане співвідношення є позитивною величиною, то управлінське рішення або проект землеустрою можуть вважатися виправданими.

Оцінка еколого-економічної ефективності проектів землеустрою щодо впорядкування землеволодінь та землекористувань здійснюється з метою визначення допустимості реалізації проектних рішень або проектів в цілому щодо попередження можливих несприятливих впливів цієї діяльності на земельні ресурси та навколишнє середовище i визначення пов'язаних з ними соціальних, економічних й інших наслідків [5].

Для визначення еколого-економічної ефективності нами пропонується методика еколого-економічної оцінки землекористування, яка представляє виражений у грошах максимально можливий ефект від їх комплексного використання (відповідних земельних угідь) 3 урахуванням соціальних і екологічних функцій. Показником еколого-економічної оцінки землекористування $є$ його вартість, яка обумовлена цінністю для суспільства людей та виражена показником загальної економічної цінності або іншими показниками, що формують загальну економічну цінність. До таких показників відносять: вартість використання, вартість не використання, вартість відкладеної альтернативи, вартість існування та успадкування. Вартість землекористування обумовлена корисністю для конкретної людини, виражається за допомогою окремих показників ринкової й неринкової вартості відповідних земельних угідь та територій водного простору, не включених до суші.

Основою оцінювання ефективності організації природоохоронного землекористування $\epsilon$ трьохрівневий підхід до оцінювання: оцінка ефективності структури землекористування за його типами і підтипами та функціональним використанням земель і інших природних ресурсів; оцінка ефективності процесу управління земле- та природокористуванням; оцінка ефективності екологічної цілісності землекористування територій і об'єктів природно-заповідного фонду або структурних елементів екомережі України. Перше, стосується структури землекористування територій і об'єктів природно-заповідного фонду або структурних елементів екомережі, яке 
визначає параметри для оцінювання адекватності структури природоохоронного землекористування або системи екологічної мережі й надає критерії для визначення тенденцій формування природоохоронного землекористування. Друге, стосується процесів управління землета природокористуванням територій і об'єктів природно-заповідного фонду або структурних елементів екомережі і передбачає оцінювання різних елементів управління. Третє, стосується екологічної цілісності територій і об'єктів природно-заповідного фонду або структурних елементів екомережі, а саме таких елементів як екологічні процеси та функціонування екосистеми, а також загрози та тиски, з якими стикається природоохоронне землекористування в їх межах.

Висновки. Під формуванням природоохоронного землекористування, розуміється складний і тривалий процес організаційно-господарських, еколого-економічних, інженернотехнічних і правових змін складу земельних угідь і функціонального використання земель, які впливають на співвідношення територіальних умов здійснення землекористування, зокрема, збільшення площі екологостабілізуючих угідь, формування культурних ландшафтів і територій та об'єктів природно-заповідного фонду, зміну режиму землекористування й інтенсивності використання земельних угідь. Формування системи природоохоронного землекористування $\epsilon$ динамічним процесом, який повинен регулюватися в інтересах усього суспільства. Його регулювання - найважливіше завдання державного управління земельними та іншими природними ресурсами та землекористуванням. На формування раціональної системи природоохоронного землекористування спрямовані політичні, правові, екологічні, економічні й адміністративні заходи державних органів. Одним 3 механізмів організації й удосконалення природоохоронного землекористування є його організація методом землеустрою.

Формування природоохоронного землекористування, в умовах нових земельних відносин, має здійснюватися на основі еколого-економічної цінності природних ресурсів i біорізноманіття, природних ландшафтів, майже не змінених господарською діяльністю людини або в результаті реконструкції природно-господарських систем землекористування, ідентифікації прав власності на земельні та інші природні ресурси тощо, методом землеустрою. Відповідно, при трансформації природних ландшафтів в агроландшафти будуть забезпечуватися оптимальні умови для життєдіяльності біоценозів на базі раціонального природокористування. Такий підхід обумовлює необхідність обов' язкової розробки проектів землеустрою територій територіальних, в тому числі об'єднаних, громад. Відповідно, у проектах землеустрою територій сільських (селищних) рад обов'язково слід вирішити завдання територіальної організації використання земельних та інших природних ресурсів шляхом зонування земель за типами (підтипами) землекористування i перерозподілу земельних угідь із врахуванням наявності цінності біорізноманіття, раціонального облаштування агроландшафтів, а також передбачити обмеження (обтяження) у використанні земельних та інших природних ресурсів.

\section{ЛIТЕРАТУРА}

1. Закон України «Про екологічну мережу України» від 24.06.2004. - № 1864-IV - Відомості Верховної Ради України від 05.11.2004. - 2004 р. - № 45. - С. 1841. - С 502.

2. Землевпорядне проектування: еколого-економічні засади формування землекористування природнозаповідних територій : монографія / А. М. Третяк, І. П. Гетманьчик; КМ України, Нац. ун-т біоресурсів і природокористування України. - К., 2011. - 254 с.

3. Концепція збалансованого (сталого) розвитку агроекосистем в Україні на період до 2025 року. Наказ Мінагрополітики України від 20.08. 2003р. № 280.

4. Третяк А.М. Екологічна мережа України в контексті формування природоохоронного землекористування: стан та проблеми / А.М. Третяк // Екологічна мережа України в контексті формування природоохоронного землекористування: стан та проблеми: мат. кругл. столу, 20 березня 2015 року. - К.: МВЦ «Медінформ», 2015. - С. 5-27.

5. Третяк А.М. Землевпорядне проектування: Організація землекористування структурних елементів екомережі України на місцевому рівні: навч. посіб./ А.М. Третяк., В.М. Третяк, Л.А. Гунько Херсон.: Олді-Плюс, 2016. - 184 с.

6. Третяк А.М., Третяк В.М., Гунько Л.А., Гетманьчик І.П. Організація землекористування ділянок природно-заповідного фонду. - Монографія. К. КОМПРИНТ: 2019. - 183 с. 